\title{
Analisis Dislikes To Likes Ratio Youtube Pada 5 Universitas Terbaik Di Indonesia Tahun 2021
}

\author{
Putu Andy Novit Pranartha \\ tuandy27@gmail.com
}

\begin{abstract}
Youtube is a social media application that allows uploading and watching videos from content creators around the world. Youtube also allows users to create free-length videos accompanied by subtitles. In Indonesia, there are 170 million million active users, making Indonesia the country with the largest Youtube users in the world. With this content creators who have many subscribers and millions of views can generate extraordinary income from the Youtube application. But there are conditions that must be met in monetizing a Youtube account. The 5 best universities in Indonesia in 2021 that use Youtube as their content platform, namely Gadjah Mada University, Bogor Agricultural University, Sepuluh Nopember Institute of Technology, University of Indonesia, and Airlangga University. The purpose of this study is to calculate the credibility of the Youtube account performance of the 5 best universities in Indonesia in 2021. The research method used is a quantitative exploratory method. The results of this study indicate that the Bogor Agricultural University is ranked first and has the best credibility of the Youtube account performance of its four competitors.
\end{abstract}

\begin{abstract}
ABSTRAK
Youtube merupakan aplikasi sosial media yang memungkinkan mengupload dan menonton banyak video dari konten kreator seluruh dunia. Youtube juga memungkinkan penggunanya membuat video berdurasi bebas yang disertai dengan subtitel. Di Indonesia terdapat 170 jutaan juta pengguna yang aktif sehingga menjadikan Indonesia sebagai negara dengan pengguna Youtube terbesar di dunia. Dengan ini konten kreator yang banyak memiliki subscriber dan view jutaan dapat menghasilkan penghasilan yang luar biasa dari aplikasi Youtube. Tetapi ada syarat yang harus ditempuh dalam monetisasi akun Youtube. Adapun 5 Universitas terbaik di
\end{abstract}


Indonesia tahun 2021 yang memanfaatkan Youtube sebagai platform kontennya, yaitu Universitas Gadjah Mada, Institut Pertanian Bogor, Institut Teknologi Sepuluh Nopember, Universitas Indonesia, dan Universitas Airlangga. Tujuan dari penelitian ini yaitu untuk menghitung kredibilitas dari performa akun Youtube 5 Universitas terbaik di Indonesia tahun 2021. Metode penelitian yang digunakan adalah metode eksploratif kuantitatif. Hasil dari penelitian ini menunjukan bahwa Institut Pertanian Bogor mendapatkan peringkat pertama dan memiliki kredibilitas performa akun Youtube yang terbaik dari empat pesaingnya.

Keywords: Youtube, Video Likes Youtube; Video Dislikes Youtube; Credibility Account Youtube.

\section{PENDAHULUAN}

Teknologi Informasi dan Komunikasi adalah payung besar terminologi yang mencakup seluruh peralatan teknis untuk memproses dan menyampaikan informasi (Haris Budiman. 2017). Saat ini teknologi informasi dan komunikasi yang berkembang pesat adalah adanya media sosial. Dimana media sosial ini sebagai wadah kita dalam bersosialisasi baik itu dituangkan dalam bentuk komunikasi ataupun yang lainnya. Teknologi komunikasi merupakan penerapan prinsip-prinsip keilmuan komunikasi untuk memproduksi suatu item material bagi efektifitas dan efisisensi proses komunikasi (D. Setiawan 2018).

Dengan perkembangan yang pesat ini menjadikan media sosial sebagai media komunikasi tercepat dan aman. Maka dari itu media social memberikan berbagai dampak bagi dunia komunikasi yang dulunya masih memakai pulsa dalam menelpon dan sms tetapi sekarang sudah menggunakan kuota internet dalam menelpon sekaligus video call dan chatting. Salah satu contoh aplikasi media sosial yang ramai digunakan dan juga bisa sebagai mata pencaharian yaitu Youtube. Aplikasi YouTube adalah sebuah situs web media sosial berbagi video yang dibuat oleh tiga mantan karyawan PayPal pada Februari 2005. Situs web ini memungkinkan pengguna mengunggah, menonton, dan berbagi videoAplikasi Youtube ini sangat banyak pengguna yang aktif. Konten creator baru banyak bermunculan karena mereka tahu bahwa bisa menghasilkan uang dari aplikasi Youtube.

Melalui Youtube pengguna juga bisa mencari berbagai informasi dengan cara melihat tayangan. Tidak hanya itu, Youtube dimanfaatkan bukan sekedar hiburan tetapi juga interaksi sosial dalam bentuk komentar, mencari, serta memberikan informasi (Yunita, Nazaruddin, and Nailis 
2019). Kehadiran aplikasi Youtube di Indonesia membuat banyaknya artis Indonesia yang membuat channel dan selalu upload video sebagai konten kreator di aplikasi Youtube. Aplikasi ini mampu memberikan penghasilan yang lumayan bagi konten kreator. Pengguna aktif aplikasi Youtube di Indonesia diperkirakan mencapai angka 170 juta pengguna atau 93,8 persen dari total keseluruhan populasi 181,9 juta pengguna internet berusia 16-64 tahun (Novianty and Prastya 2021). Sekarang top universitas di Indonesia juga sudah memiliki channel Youtube secara khusus dibahas pada penelitian ini diantaranya Universitas Indonesia, Universitas Gadjah Mada, Universitas Airlangga, Institut Teknologi Sepuluh Nopember, Institut Pertanian Bogor.

Penelitian ini menggunakan metode eksploratif kuantitatif, dan akan menghitung menggunakan rasio-rasio yang ada pada Youtube. Pada sosial media Youtube ada enam variable yang bisa digunakan dalam mencari rasio dan relevan digunakan sebagai media ukur kredibilitas akun yang ada. Penelitian ini hanya berfokus untuk menghitung kredibilitas Video Dislikes to Video Likes Ratio pada 5 Universitas Terbaik di Indonesia tahun 2021. Adapun 5 Universitas Terbaaik di Indonesia tahun 2021, diantaranya yaitu: Universitas Gadjah Mada, Institut Pertanian Bogor, Institut Teknologi Sepuluh Nopember, Universitas Indonesia, Universitas Airlangga (Berita Terkini 2021). Tujuan dari penelitian ini adalah mengetahui kredibilitas performa dari akun Youtube 5 Universitas Terbaik di Indonesia tahun 2021 menggunakan Video Dislikes to Video Likes Ratio.

\section{TINJAUAN PUSTAKA}

Media sosial terus berkembang hingga saat ini, baik secara kuantitas maupun kualitasnya. Media sosial tergolong ke dalam bagian dari new media dimana para penggunanya bisa dengan mudah berpatisipasi, berbagi, dan menciptakan. Sebagai contoh beberapa media sosial yang terdapat di Indonesia antara lain seperti Line, Whatapp, Twitter, Facebook, Instagram, YouTube, Blog, dan lain-lain (Aditya 2020).

Pada penelitian ini berfokus pada aplikasi YouTube. YouTube adalah database video yang paling popular di dunia internet, atau bahkan mungkin yang paling lengkap dan variatif. YouTube merupakan situs yang berfungsi untuk menonton kumpulan video yang diunggah dari seluruh dunia dan dapat ditonton dimana saja asalkan kita terhubung dengan internet (Hendika Permana 2021). 
Profit yang dihasilkan oleh Youtuber terbilang penghasilan yang tinggi. Beberapa Youtuber ternama Indonesia serta Youtuber lainnya hanya perlu membuat konten menarik dan mengumpulkan like, subscribe dan komentar dari pemirsa Youtube. Seiring dengan banyaknya pengguna internet di Indonesia maka profesi Youtuber menjadi profesi yang menjanjikan (Nur'aini 2021).

Setelah peneliti melakukan telaah tentang penelitian yang terkait, ada sumber yang memiliki keterkaitan dengan penelitian yang sedang dilakukan. Berikut adalah penelitian yang dilakukan oleh I Putu Hendika Permana (2021) yang berjudul “Analisis Rasio Pada Akun Youtube Untuk Penelitian Kualitatif Menggunakan Metode Ekploratif “. Tujuan dari penelitian ini adalah untuk mendapatkan nilai rasio dengan menguji beberapa variable yang terkait sehingga dapat menentukan kredibilitas sebuah akun YouTube yang dapat dinilai peformanya berdasarkan rasio yang telah didapatkan. Akun yang dijadikan sampel adalah akun YouTube dari Justin Bieber dengan video yang berjudul "Justin Bieber - Anyone (Live From NYE)". Dan data-data akan dikumpulkan berdasarkan variable yang telah ditetapkan.

\section{METODE PENELITIAN}

Penelitian ini menggunakan metode eksploratif kuantitatif untuk mengetahui kredibilitas dari peforma akun YouTube 5 Universitas Terbaik di Indonesia Pada Tahun 2021. Metode eksploratif deskriptif, yaitu mengumpulkan data fakta yang telah tersedia di lapangan melalui pencatatan dan pengamatan secara terperinci dan sistematik kemudian dilakukan analisa data berdasarkan data kualitatif dan kuantitatif (Bawinto, Mongi, and Kaseger 2015).

Tujuan dari penelitian ini yaitu mengetahui nilai kredibillitas dari performa akun YouTube 5 Universitas Terbaik di Indonesia Pada Tahun 2021. Untuk mendapatkan hasil yang terbaik, maka perlu dilakukan beberapa langkah dalam penelitian ini, sehingga pada akhirnya mendapatkan peringkat pertama akun YouTube Universitas Terbaik di Indonesia yang mempunyai peforma terbaik. Berikut langkah-langkah untuk mendapatkan peringkat tersebut dalam penelitian ini, diantaranya:

1. Melakukan Eksplorasi Pada Website Untuk Menentukan Objek Yang Akan Dianalisa

Eksplorasi ini dilakukan dengan mencari sumber di beberapa halaman website terpercaya yang menyediakan informasi dan data yang akan kita teliti pada penelitian ini. Setelah eksplorasi selesai dilakukan, sehingga ditemukan nama-nama 5 
Universitas terbaik di Indonesia yang akan dijadikan objek analisa. Setelah eksplorasi selesai dilakukan pada halaman website, maka selanjutnya adalah mencari nama akun YouTube dari kelima Universitas tersebut. Pastikan semua universitas memiliki akun pada aplikasi sosial media YouTube.

2. Menghitung Nilai Rata-Rata Variable Dari 5 Universitas Terbaik di Indonesia

Pada langkah ini, peneliti menghitung nilai rata-rata dari variable video dislikes dan variable video likes pada 10 video terbaru. Variabel adalah sesuatu hal yang terbentuk apa saja yang di tetapkan oleh peneliti untuk di pelajari, sehingga di peroleh informasi tentang hal tersebut, dan kemudian di tarik kesimpulannya (A. Setiawan 2017). Jenis variabel ada bermacam-macam, diantaranya adalah variabel Independen, dependen, moderator, intervening, dan kontrol (A. Setiawan 2017). Untuk menghitung nilai ratarata dari variabel video dislikes dan variabel video likes yaitu dengan cara mengambil minimal 10 postingan terbaru yang selanjutnya dihitung dengan bantuan excel sehingga mendapatkan nilai rata-ratanya.

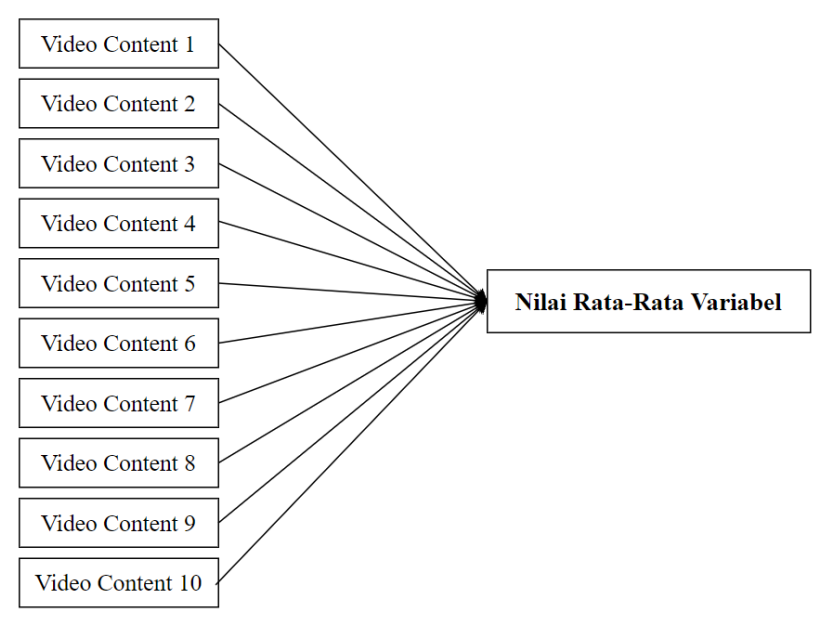

Gambar 1. Analisa Nilai Rata-Rata Variabel.

Jurnal Analisis (2021)

3. Menghitung Nilai Kredibilitas Rasio

Pada tahap ini telah memasuki tahap perhitungan nilai kredibilitas setiap akun dengan cara menggunakan nilai rata-rata yang telah didapat. Untuk mendapatkan nilai kredibilitas rasio dari video dislikes dan video likes pada YouTube bisa dilakukan dengan cara membagi nilai variable pertama dengan nilai variable kedua. Jika video dislikes memiliki nilai rata-rata 5 dan video likes memiliki nilai rata-rata 10 , maka cara 
menghitungnya dengan cara $5 / 10=0,5$. Dengan begitu nilai kredibilitas rasio YouTube dari video dislikes to video likes rasionya adalah 0,5 .

4. Menentukan Karakteristik dan Peringkat Pada 5 Akun YouTube Universitas Terbaik di Indonesia

Pada langkah terakhir ini hal pertama yang harus dilakukan adalah mendapatkan nilai karakteristik setiap akun YouTube dengan cara, jika karakteristik rasio merupakan rendah, maka objek yang memiliki nilai terendah akan mendapatkan angka 5 dan objek yang memiliki nilai tertinggi akan mendapatkan angka 1. Namun jika rasio memiliki karakteritik tinggi maka objek yang mendapatkan nilai tinggi akan mendapatkan angka 5 dan objek yang mendapatkan nilai terendah akan mendapatkan angka 1. Setelah mendapatkan hasil kredibilitas ratio maka dapat disimpulkan objek yang mana mendapatkan karakteristik terbesar akan memperoleh peringkat 1 dan karakteristik paling kecil akan mendapatkan peringkat terbawah.

\section{HASIL DAN PEMBAHASAN}

Akun youtube dari 5 universitas terbaik di Indonesia tahun 2021, diantaranya:

\section{Universitas Gadjah Mada}

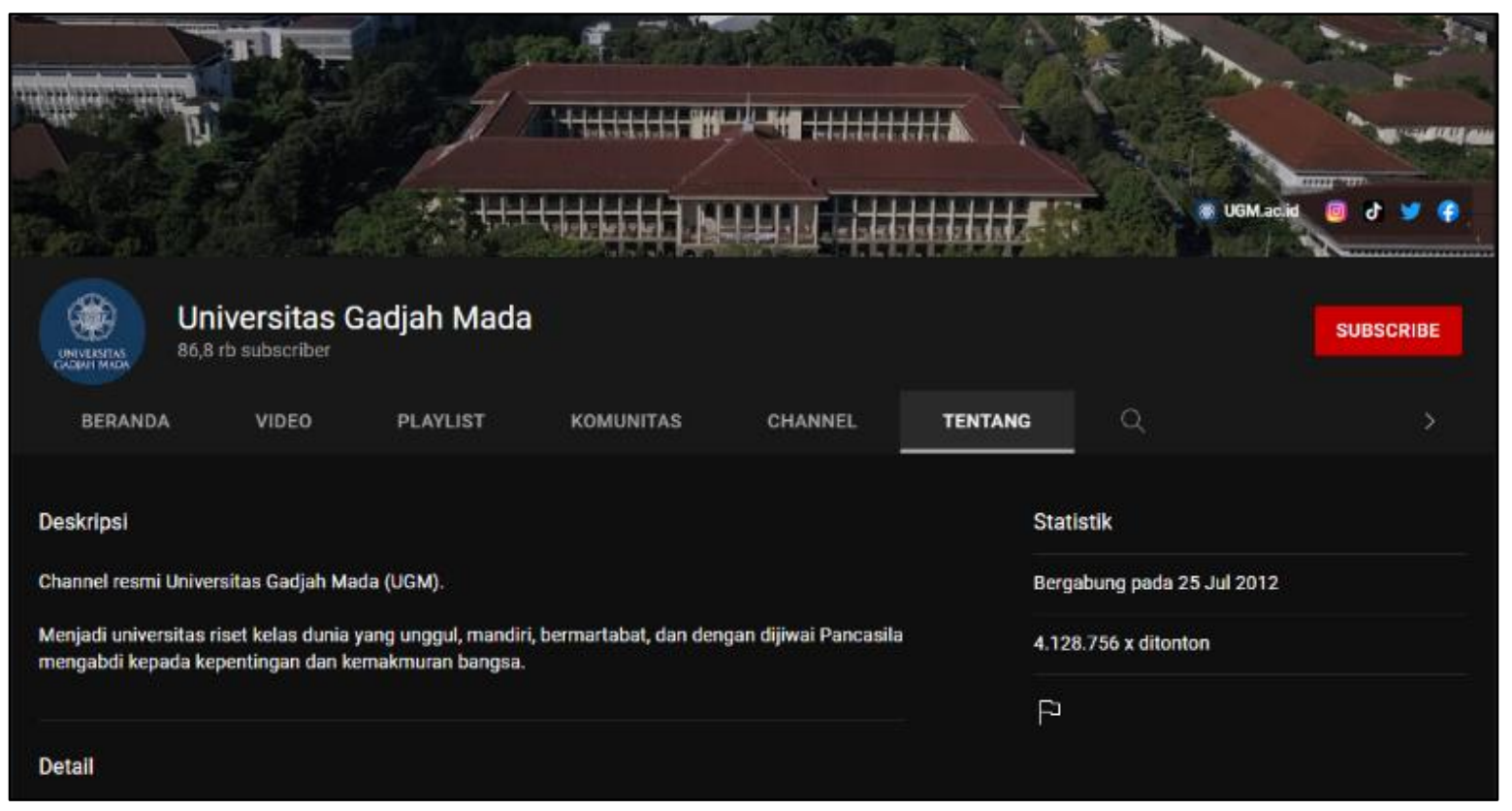

Gambar 1. Akun Youtube Universitas Gadjah Mada

Sumber: https://www.youtube.com/user/UGMOfficial (akses pada 02-12-2021)\ 


\section{Institut Pertanian Bogor}

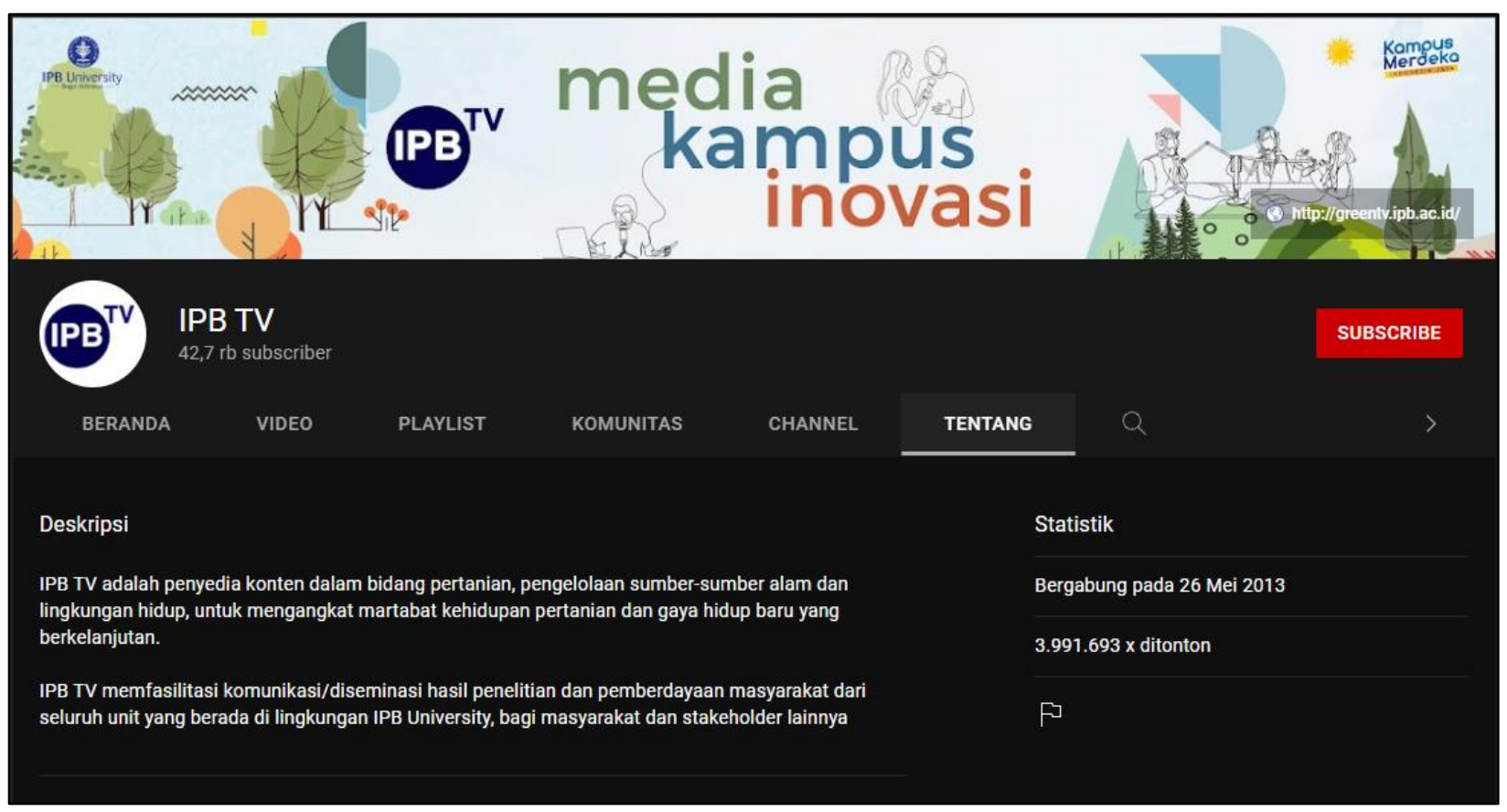

Gambar 2. Institut Pertanian Bogor

Sumber: https://www.youtube.com/channel/UC5tlNLMFpmrY2zUvQSQS-lw (aksed pada 02-12-2021)

\section{Institut Teknologi Sepuluh Nopember}

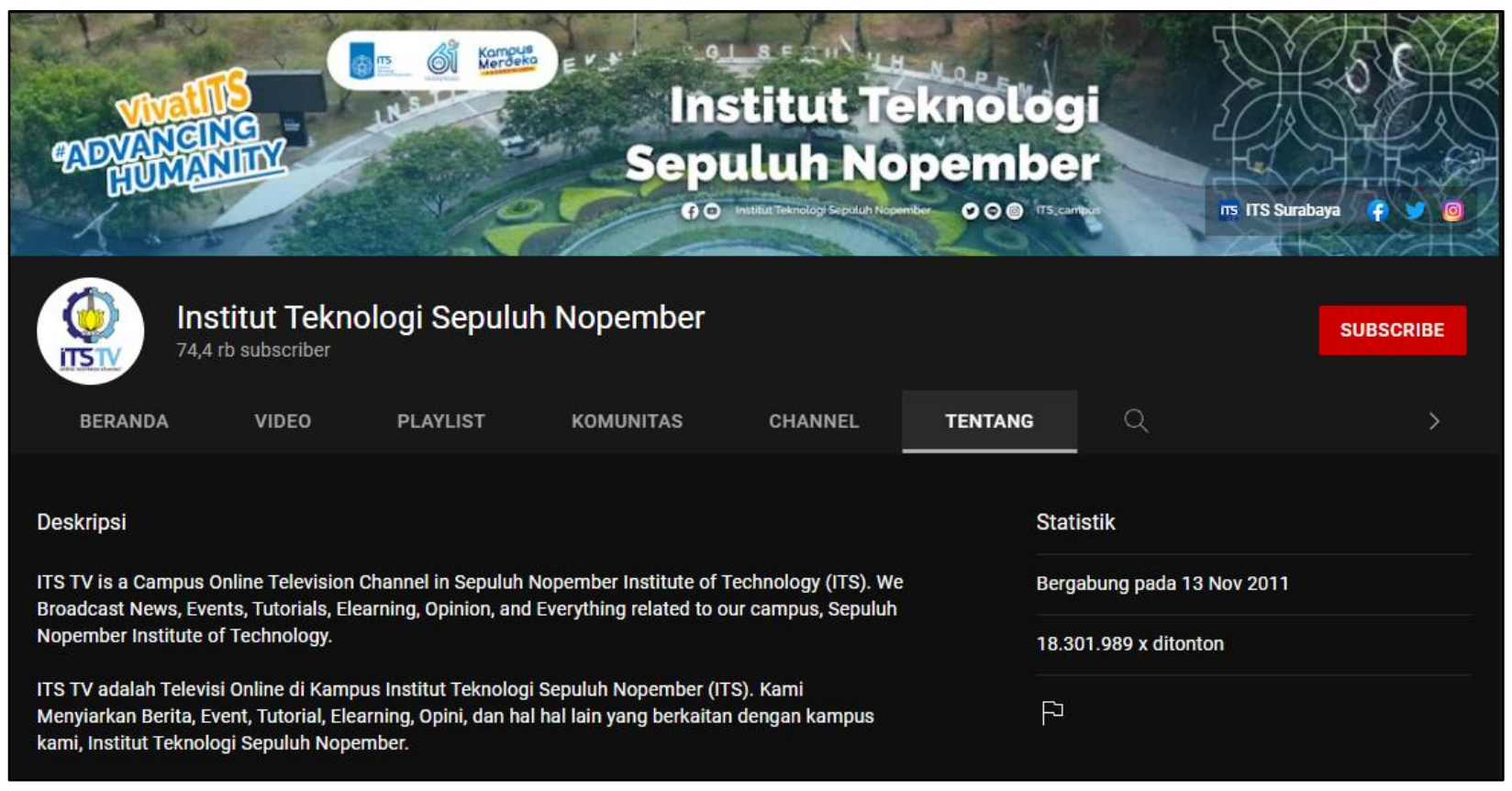

Gambar 3. Institut Teknologi Sepuluh Nopember

Sumber: https://www.youtube.com/c/itseurekatv (akses pada 02-12-2021) 


\section{Universitas Indonesia}



Gambar 4. Universitas Indonesia

Sumber: https://www.youtube.com/user/UIUpdate2 (akses pada 02-12-2021)

\section{Universitas Airlangga}

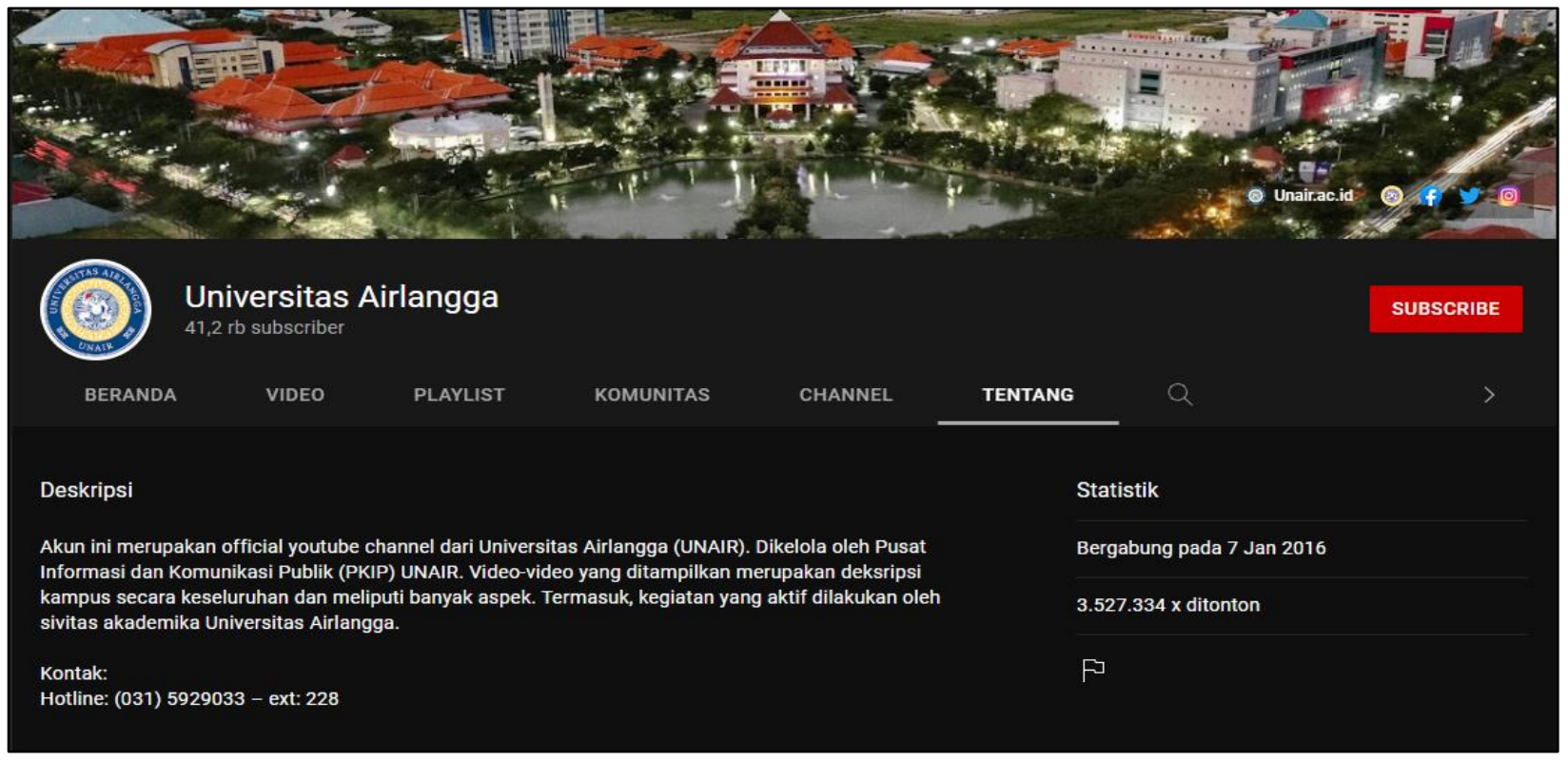

Gambar 5. Universitas Airlangga

Sumber: https://www.youtube.com/channel/UCUYwloXmWyNZplsqg4MVERw (akses pada 02-12-2021) 
Dari kelima akun Youtube 5 Universitas Terbaik di Indonesia Pada Tahun 2021, peneliti menemukan nilai dari masing-masing variabel yang ada untuk menghitung rasio dislikes to likes dari setiap akun. Pada akun Youtube terdapat 6 variabel, diantaranya yaitu:

1. Subscriber

2. Video Likes

3. Video Dislikes

4. Video Comments

5. Video Share

6. Video Views

Dari keenam variabel tersebut peneliti hanya fokus untuk menemukan hasil dari 2 variabel, yaitu:

1. Video Dislikes

\section{Video Likes}

Dari kedua variabel tersebut kemudian dianalisa sehingga menemukan nilai rata-rata dari variabel video dislikes dan variabel video likes. Untuk menghitung nilai rata-rata dari variabel video dislikes dan variabel video likes yaitu dengan cara mengambil 10 postingan terbaru kemudian di hitung sehingga menemukan nilai rata-rata dari masing-masing variabel. Berikut merupakan tabel nilai rata-rata dari masing-masing 5 universitas terbaik di Indonesia, yaitu:

Tabel 1. Analisa Nilai Rata-Rata Nilai Variabel Video Dislikes dan Video Likes Akun Youtube Universitas Gadjah Mada

\begin{tabular}{|c|c|c|}
\hline No & DISLIKES & LIKES \\
\hline 1 & 0 & 31 \\
\hline 2 & 0 & 15 \\
\hline 3 & 0 & 103 \\
\hline 4 & 0 & 43 \\
\hline 5 & 0 & 48 \\
\hline 6 & 3 & 107 \\
\hline 7 & 0 & 53 \\
\hline
\end{tabular}




\begin{tabular}{|c|c|c|}
8 & 3 & 25 \\
\hline 9 & 0 & 42 \\
\hline 10 & 0 & 24 \\
\hline Total & $\mathbf{0 , 6}$ & $\mathbf{4 9 , 1}$ \\
\hline
\end{tabular}

Tabel 2. Analisa Nilai Rata-Rata Nilai Variabel Video Dislikes dan Video Likes Akun Youtube Institut Pertanian Bogor

\begin{tabular}{|c|c|c|}
\hline No & DISLIKES & LIKES \\
\hline 1 & 0 & 25 \\
\hline 2 & 0 & 9 \\
\hline 3 & 0 & 27 \\
\hline 4 & 0 & 54 \\
\hline 5 & 0 & 222 \\
\hline 6 & 1 & 20 \\
\hline 7 & 1 & 14 \\
\hline 8 & 0 & 18 \\
\hline 9 & 1 & 27 \\
\hline 10 & 1 & $\mathbf{5 1 , 1}$ \\
\hline Total & $\mathbf{0 , 4}$ & 95 \\
\hline
\end{tabular}

Sumber: pengolah data excel (2021)

Tabel 3. Analisa Nilai Rata-Rata Nilai Variabel Video Dislikes dan Video Likes Akun Youtube Institut Teknologi Sepuluh Nopember

\begin{tabular}{|c|c|c|}
\hline No & DISLIKES & LIKES \\
\hline 1 & 0 & 15 \\
\hline 2 & 0 & 15 \\
\hline 3 & 0 & 47 \\
\hline 4 & 7 & 235 \\
\hline 5 & 0 & 146 \\
\hline 6 & 0 & 14 \\
\hline
\end{tabular}




\begin{tabular}{|c|c|c|}
7 & 0 & 24 \\
\hline 8 & 6 & 262 \\
\hline 9 & 5 & 409 \\
\hline 10 & 0 & 22 \\
\hline Total & $\mathbf{1 , 8}$ & $\mathbf{1 1 8 , 9}$ \\
\hline
\end{tabular}

Sumber: pengolahan data excel (2021)

Tabel 4. Analisa Nilai Rata-Rata Nilai Variabel Video Dislikes dan Video Likes Akun Youtube Universitas Indonesia

\begin{tabular}{|c|c|c|}
\hline No & DISLIKES & LIKES \\
\hline 1 & 4 & 495 \\
\hline 2 & 0 & 6 \\
\hline 3 & 0 & 15 \\
\hline 4 & 1 & 28 \\
\hline 5 & 8 & 522 \\
\hline 6 & 0 & 8 \\
\hline 7 & 0 & 1 \\
\hline 8 & 4 & 2 \\
\hline 9 & 0 & 5 \\
\hline 10 & 0 & $\mathbf{1 0 8 , 3}$ \\
\hline Total & $\mathbf{1 , 7}$ & 1 \\
\hline
\end{tabular}

Sumber: pengolahan data excel (2021)

Tabel 5. Analisa Nilai Rata-Rata Nilai Variabel Video Dislikes dan Video Likes Akun Youtube Universitas Airlangga

\begin{tabular}{|c|c|c|}
\hline No & DISLIKES & LIKES \\
\hline 1 & 0 & 8 \\
\hline 2 & 0 & 20 \\
\hline 3 & 0 & 13 \\
\hline 4 & 0 & 12 \\
\hline 5 & 0 & 81 \\
\hline
\end{tabular}




\begin{tabular}{|c|c|c|}
6 & 16 & 1800 \\
\hline 7 & 1 & 362 \\
\hline 8 & 0 & 50 \\
\hline 9 & 7 & 360 \\
\hline 10 & 8 & 536 \\
\hline Total & $\mathbf{3 , 2}$ & $\mathbf{3 2 4 , 2}$ \\
\hline
\end{tabular}

Setelah menghitung nilai rata-rata tersebut, maka akan menemukan hasil akhir nilai rata-rata dari variabel video dislikes dan video likes.

Tabel 6. Nilai Variabel Pada Akun Youtube 5 Universitas Terbaik di Indonesia Q1-2021

\begin{tabular}{|c|c|c|c|c|c|}
\hline VARIABLE & UGM & IPB & ITS & UI & UNAIR \\
\hline DISLIKES & 0,6 & 0,4 & 1,8 & 1,7 & 3,2 \\
\hline LIKES & 49,1 & 51,1 & 118,9 & 108,3 & 324,2 \\
\hline
\end{tabular}

Sumber: pengolah data excel (2021)

Pada akun Youtube terdapat 15 rasio yang relevan digunakan untuk mengukur kredibilitas pada masing-masing akun. Namun pada penelitian kali ini hanya berfokus untuk menghitung Video Dislikes to Video Likes Ratio. Untuk menghitung kredibilitas dari masing-masing akun Youtube setiap Universitas, peneliti menghitung dengan cara: variabel 1 akan dibagi dengan variabel 2, sehingga ditemukan hasil analisisa dari rasio tersebut.

Tabel 7. Hasil Perhitungan Rasio Akun Youtube

\begin{tabular}{|c|c|c|c|c|c|c|}
\hline NO & RATIO & UGM & IPB & ITS & UI & UNAIR \\
\hline 1 & $\begin{array}{c}\text { Dislikes to } \\
\text { Likes }\end{array}$ & 0,012219959 & 0,007827789 & 0,015138772 & 0,015697138 & 0,00987045 \\
\hline
\end{tabular}

Sumber: pengolah data excel (2021)

Video Dislikes to Video Likes Ratio memiliki karakteristik yang rendah, artinya semakin rendah nilai yang dihasilkan maka semakin baik kredibilitas dari performa akun tersebut. Untuk memberikan peringkat pada masing-masing Universitas, peneliti memberikan angka 5 kepada vendor yang mendapatkan nilai terendah dan angka 1 untuk Universitas yang mendapatkan 
nilai tertinggi. Berikut merupakan tabel urutan nilai karakteristik yang dihasilkan oleh masingmasing akun universitas.

Tabel 8. Nilai Rasio Akun Youtube 5 Universitas Terbaik di Indonesia Q1-2021

\begin{tabular}{|c|c|c|c|c|}
\hline UGM & IPB & ITS & UI & UNAIR \\
\hline 3 & 5 & 2 & 1 & 4 \\
\hline \multicolumn{5}{|c|}{ 出 } \\
\hline
\end{tabular}

Dari Tabel Nilai Rasio Akun Youtube 5 Universitas Terbaik di Indonesia Q1-2021 dapat simpulkan bahwa Institut Pertanian Bogor (IPB) mendapatkan nilai tertinggi untuk rasio Video Dislikes to Video Likes. Sedangkan akun Youtube Universitas Indonesia mendapatkan nilai terendah untuk rasio ini. Jadi, pada penelitian ini Institut Pertanian Bogor (IPB) memiliki kredibilitas performa yang lebih baik dibandingkan dengan universitas yang lainnya. Berikut:

Tabel 9. Ranking Akun Youtube 5 Universitas Terbaik di Indonesia tahun 2021 berdasarkan Video Dislikes to Video Likes Ratio

\begin{tabular}{|c|c|}
\hline RANK & UNIVERSITAS \\
\hline $\mathbf{1}$ & IPB \\
\hline $\mathbf{2}$ & UNAIR \\
\hline $\mathbf{3}$ & UGM \\
\hline $\mathbf{4}$ & ITS \\
\hline $\mathbf{5}$ & UI \\
\hline
\end{tabular}

Sumber: pengolah data excel (2021)

\section{KESIMPULAN}

Tujuan dari penelitian ini adalah mengetahui kredibilitas performa dari akun Youtube 5 Universitas terbaik di Indonesia tahun 2021 menggunakan Video Dislikes to Video Likes Ratio. 5 Universitas tersebut diantaranya Universitas Gadjah Mada, Institut Pertanian Bogor, Institut Sepuluh Nopember, Universitas Indonesia, dan Universitas Airlangga. Dari kelima Universitas tersebut dapat disimpulkan bahwa:

1. Peringkat pertama diraih oleh Institut Pertanian Bogot dengan nilai 0,007827789 
2. Peringkat kedua diarih oleh Universitas Airlangga dengan nilai 0,00987045

3. Peringkat ketiga diraih oleh Universitas Gadjah Mada dengan nilai 0,012219959

4. Peringkat keempat diraih oleh Institut Teknologi Sepuluh Nopember dengan nilai 0,015138772

5. Peringkat kelima diraih oleh Universitas Indonesia dengan nilai 0,015697138 


\section{DAFTAR PUSTAKA}

Aditya, Shelby Anneshavira. 2020. "Personal Branding Reza Darmawangsa Melalui Youtube Sebagai Penyanyi Cover Korea Pop" 7 (2): 7525-36.

Bawinto, Adelia Since, Eunike Mongi, and Bertie Kaseger. 2015. "The Analysis of Moisture, PH, Sensory, and Mold Value of Smoked Tuna (Thunnus Sp.) at Girian Bawah District, Bitung City, North Sulawesi.” Media Teknologi Hasil Perikanan 3 (2): 55-65.

Berita Terkini. 2021. "5 Universitas Terbaik Di Indonesia 2021 Beserta Ulasannya." Kumparan.Com. 2021. https://kumparan.com/berita-terkini/5-universitas-terbaik-diindonesia-2021-beserta-ulasannya-1vxcjBkQb5d.

Haris Budiman. 2017. "Peran Teknologi Informasi Dan Komunikasi Dalam Pendidikan.” AlTadzkiyyah: Jurnal Pendidikan Islam 8 (1): 31-43.

Hendika Permana, I Putu. 2021. “Analisis Rasio Pada Akun Youtube Untuk Penelitian Kualitatif Menggunakan Metode Ekploratif.” Jurnal Ilmiah Media Sisfo 15 (1): 40. https://doi.org/10.33998/mediasisfo.2021.15.1.970.

“Jurnal Analisis (Studi Kasus Rasio TikTok).Docx - Google Drive.” n.d. https://drive.google.com/file/d/1aGga6IC6RkoCEu0IeJMkVuq6rRP9Y1B5/view.

Novianty, Dythia, and Dicky Prastya. 2021. "Youtube Rajai Media Sosial Indonesia." Suara.Com. 2021. https://www.suara.com/tekno/2021/02/15/153000/youtube-rajaimedia-sosial-di-indonesia.

Nur'aini, Alfi. 2021. "Monetisasi Youtube Perspektif Tafsir Maqashidi.” Jurnal Penelitian Agama 22 (1): 65-86. https://doi.org/10.24090/jpa.v22i1.2021.pp65-86.

Setiawan, Andre. 2017. "Pengaruh Gaya Kepemimpinan Partisipatif Terhadap Kinerja Karyawan Melalui Motivasi Kerja Dan Kepuasan Kerja.” Agora 5 (3): 1-7.

Setiawan, Daryanto. 2018. "Dampak Perkembangan Teknologi Informasi Dan Komunikasi Terhadap Budaya." JURNAL SIMBOLIKA: Research and Learning in Communication Study 4 (1): 62. https://doi.org/10.31289/simbollika.v4i1.1474.

Yunita, Dessy, Ahmad Nazaruddin, and Welly Nailis. 2019. "Pengaruh Youtube Advertising Terhadap Brand Awareness Dan Purchase Intention.” Jurnal Manajemen Dan Kewirausahaan 7 (1). https://doi.org/10.26905/jmdk.v7i1.2538. 